\title{
A CRITICAL ANALYSIS ON THE LAW'S ABILITY TO ERADICATE RACISM IN (POST) APARTHEID SOUTH AFRICA
}

\author{
by Akhona Boloko*
}

\section{Introduction}

It has been over two decades since apartheid, which was declared a crime against humanity, ended. A Truth and Reconciliation Commission (hereafter TRC) was established in 1995 with the hopes of, amongst other things, promoting national unity and reconciliation. ${ }^{1}$ Whilst the TRC received many criticisms, it was also praised for promoting national unity and reconciliation. However recent social media posts which were seen as racist have shattered the picture of a reconciled nation free from racism. ${ }^{2}$ The government's response to these manifestations of racism is of particular interest in this article. The government wants to enact legislation to criminalise racism as a way to not only deter, but to eradicate racism. ${ }^{3}$ In this article I will be critically analysing the law's ability to eradicate racism and ultimately argue that while legislation may address individual discriminatory acts, it fails to address racism as a structural power system. I will do this by firstly determining the success of the TRC in achieving national unity and reconciliation. Secondly, I will briefly analyse post-apartheid South Africa through Antjie Krog's book 'A change of tongue'. Lastly, I will critically discuss the need to utilise a Critical Race Theory and African Jurisprudence in post-apartheid South Africa.

* Third year LLB student, University of Pretoria.

1 Promotion of National Unity and Reconciliation Act 34 of 1995.

2 Recent incidences on social media include a real estate agent, Penny Sparrow, likening black beach-goers to monkeys, an economist Chris Hart stating that apartheid victims are becoming more entitled and fostering hate against minorities and Kelly-Ann Wade stating that an ape has more intelligence than Jacob Zuma. See Banks 'Social media and the reawakening of racism in South Africa' http://buzzsouthafrica.com/social-media-reawakening-racism-southafrica/ (accessed 18 October 2016). The law profession has not been immune as evidenced by comments made by high court judge Mabel Jansen who claimed that rape is part of black culture. See $D$ Bendile \& $M$ Lindeque 'Judge Jansen's rape comments spark calls for effective transformation' http://ewn.co.za/2016/05/ 10/ANC-More-needs-to-be-done-to-transform-judiciary (accessed 18 October 2016).

3 M Mothapo 'Specific law needed to criminalise racism and promotion of apartheid - Office of ANC Chief Whip' http://www.politicsweb.co.za/news-and-analysis/ specific-law-needed-to-criminalise-racism-and-prom (accessed 28 April 2016). 
I will adopt the approaches of Critical Race Theory (CRT) and African Jurisprudence, because I believe that these two approaches are both necessary to address racism through their different perspectives. CRT as discussed later specifically involves the critique of the law and its role in constructing, producing and rationalising racial inequality whilst African Jurisprudence provides practical steps that need to be taken by government.

It is important that I define and clearly set out my understanding of the racism that I propose is still rife in South Africa. In this regard Alfred Moraka provides some guidance. Moraka defines racism as a functioning structural power system that operates through historical, political, social, and economic power that privileges, secures and protects the interests of those that are positioned as white in the world at the expense of those who are positioned as black. ${ }^{4}$ Since racism is a structural power system the absence of obvious racial discrimination creates the impression of racial neutrality, which persuades white and privileged black people to believe that racism is no longer an issue. ${ }^{5}$ If racism is a structural power system, then it will require more than mere enacted legislation to dismantle it.

\section{The success of the TRC in achieving national unity and reconciliation}

The TRC was tasked with the difficult task of picking up the broken pieces of South Africa left by the oppressive system of apartheid and finding a way to move the country forward whilst still acknowledging the traumatic past. The TRC decided to focus on uncovering the truth and reconciling the country. ${ }^{6}$ In order to achieve the above goals the Human Rights Violation Committee, the Reparation and Rehabilitation Committee and the Amnesty Committee were established. ${ }^{7}$ The Amnesty Commission focused on the perpetrators by providing amnesty to those perpetrators who committed politically motivated crimes and provided full disclosure about such crimes. On the other hand the other two commissions focused on the victims. ${ }^{8}$ What is interesting to note about these committees is that the Amnesty Committee gave decisions that were binding on the TRC and the

4 A Moraka 'Reflections on the Mabille saga and the Anti-Racist Forum at the University of Pretoria' (2014) 8 PULP Fictions: Race, Ideology and the University 8.

5 J Modiri “Towards a “(post-)Apartheid” critical race jurisprudence: “divining our racial themes"' (2012) 27 SA Public Law 235.

6 Promotion of National Unity and Reconciliation Act 34 of 1995.

7 A Allan \& MM Allan 'The South African Truth and Reconciliation Commission as a therapeutic tool' (2000) 18 Behavioural Sciences \& the Law 466.

8 M Mamdani 'A diminished truth' in WG James \& $L$ Van de Vijver After the TRC: reflections on truth and reconciliation in South Africa (2001) 58. 
government while the other two committees gave decisions that were merely labelled as recommendations. ${ }^{9}$

The result of the Amnesty Committee was that a total of 5392 applications were refused and 849 applications were granted. ${ }^{10}$ The TRC further declared that approximately 20000 people were victims and fewer than 10000 people were perpetrators. ${ }^{11}$ The TRC ultimately only focused on what was considered gross violations under apartheid and other violations, such as land dispossession and forced removals, were not addressed because they were legal under the apartheid regime. ${ }^{12}$ The result of the TRC was that it only focused on political reconciliation between state agents and political activists and therefore social reconciliation between the beneficiaries of apartheid and victims was largely not achieved. ${ }^{13}$

Albie Sachs is one of the people who believe that the TRC was successful. Sachs maintains that the TRC allowed the country to develop a single narrative and common history and as a result foundations of national reconciliation were largely achieved. ${ }^{14}$ However this positive outlook does not reflect the true state of affairs as seen in a study done on Afrikaner, Xhosa and English people in 2004 where all three groups of people believed that the TRC was not effective in bringing about reconciliation. ${ }^{15}$ Whilst the TRC did not directly have the eradication of racism as its mandate, I argue that achieving national unity and reconciliation requires that racism no longer be a barrier between people. The fundamental question that the TRC left unanswered was how those who continue to be the beneficiaries of apartheid can reconcile and live together with those people who continue to be the victims of apartheid. ${ }^{16}$

However, there are those whose views about the success of the TRC in achieving reconciliation are more in line with the actual effectiveness of the TRC in achieving reconciliation. Firstly, Krog questions the whole purpose of even embarking on a mission for reconciliation when there has been no previous relationship that was in place that has to be reconciled. ${ }^{17}$ Krog rather suggests that

9 Mamdani (n 8 above) 58.

10 Department of Justice \& Constitutional Development http://www.justice.gov.za/ trc/amntrans/index.htm (accessed 11 September 2016).

11 TA Borer 'A taxonomy of victims and perpetrators: human rights and reconciliation in South Africa' (2003) 25 Human Rights Quarterly 1102.

12 Mamdani (n 8 above) 60.

13 As above.

14 A Sachs The strange alchemy of life and law (2009) 87.

15 E Vora \& JA Vora 'The effectiveness of South Africa's Truth and Reconciliation Commission perceptions of Xhosa, Afrikaaner and English South Africans' (2004) 34 Journal of Black Studies 310.

16 Mamdani (n 8 above) 59.

17 A Krog Country of my skull (2002) 109. 
'conciliation' be used as it would be more appropriate than 'reconciliation'. ${ }^{18}$ Krog further makes a distinction between what reconciliation means for Desmond Tutu and Thabo Mbeki. For Tutu reconciliation is the beginning of the transformative process whilst for Mbeki reconciliation can only occur after total transformation has taken place. ${ }^{19}$ If we are to look at reconciliation through Mbeki's eyes then reconciliation has certainly not taken place because there has been no total transformation. The lack of transformation is easily evident in the fact that the income gap between rich and poor has increased between 2000 and 2011.20 In addition 54\% of South Africans according to latest statistics live below the poverty line which translates into 27 million people living on R779 or less per person every month. ${ }^{21}$ Therefore, in terms of transformation, South Africa still has a long way to go.

Mogobe Ramose further takes away from the credibility of the TRC in achieving reconciliation by specifically highlighting the absence of justice from the process of reconciliation. ${ }^{22}$ Ramose believes that issues of natural and historical justice are to be resolved and therefore the absence of justice in the reconciliation process amounts to the continuation of enslavement of the colonised. ${ }^{23}$ This omission of justice in the TRC was further questioned in the Azanian People's Organisation $v$ The President of the Republic of South Africa case where victims or the dependents of the victims of politically motivated crimes were not allowed to hold perpetrators civilly or criminally liable, because of the amnesty granted by the TRC. ${ }^{24}$ The court found that amnesty against criminal and civil liability was justified, because it was a means to an end in the sense that perpetrators would only reveal the truth if they were protected from punishment. 25

The South African Reconciliation Barometer is an annual public opinion survey which provides a very good indication on where South Africans stand when it comes to reconciliation. The 2015 survey found that most South Africans believed that reconciliation will remain

18 Krog (n 17 above) 109.

19 Krog (n 17 above) 110.

20 AN Hodgson 'South Africa - The most unequal income distribution in the world' http://blog.euromonitor.com/2012/06/south-africa-the-most-unequal-incomedistribution-in-the-world.html (accessed 12 September 2016).

21 L Grant 'Infographic: Poverty in South Africa' http://mg.co.za/data/2015-02-05 infographic-poverty-in-south-africa (accessed 12 September 2016).

22 MB Ramose 'Reconciliation and reconciliation in South Africa' (2012) 5 Journal on African Philosophy 21.

23 Ramose (n 22 above) 21.

241996 (4) SA 671 (CC) para 7.

25 Azanian People's Organization (n 24 above) para 36. 
impossible as long as those who were disadvantaged by apartheid remain poor. ${ }^{26}$ This echoes the sentiments of Thabo Mbeki that reconciliation cannot take place without total transformation. The survey further revealed that $61.4 \%$ of South Africans believe that race relations since 1994 have either remained the same or deteriorated, only $35.6 \%$ felt that they do not experience racism in their daily lives and $67.3 \%$ of people admitted to having little or no trust in people of other racial groups. ${ }^{27}$ These results highlight the fact that reconciliation has not taken place and will continue to be delayed until South Africa makes a concerted effort to address and correct the disastrous effects of apartheid. This will include doing more than simply creating legislation to deter individual acts of racism.

Ramose expresses concern about the fact that the Convention for a Democratic South Africa (CODESA) talks, which resulted in the interim constitution and ultimately gave effect to the TRC, were labelled as 'negotiations'. ${ }^{28}$ Firstly, the negotiations were concluded in South Africa and not on neutral grounds and therefore the weaker party was unable to fully express themselves because they were in the environment of the stronger party. ${ }^{29}$ Secondly, Ramose describes these negotiations as undemocratic because not everyone was consulted about the negotiations and important issues of natural and historical justice were not addressed. ${ }^{30}$ If the foundation upon which the constitution was based on was itself problematic, then it can only be expected that the TRC would itself lay a poor foundation for reconciliation and national unity. The TRC laid a poor foundation, because it did not provide for justice nor did it provide an effective way to move from a racist society to a society free from racism. Whilst the TRC did provide reparations for political activists and their families, I do not believe that this qualifies as justice for the rest of the previously disadvantaged people, who suffered through apartheid and continue to suffer and live with the consequences.

In Apartheid Futures and the Limits of Racial Reconciliation the author, Achille Mbembe, illustrates how post-apartheid South Africa still lacks racial reconciliation despite the efforts of the TRC. Firstly, he highlights that for white beneficiaries, reconciliation means that blacks should forget about the past injustices and that the present white generation can no longer be held responsible for racial discrimination committed before they were born and, because of this, Www.ijr.org.za/uploads/IJR_SARB_2015_WEB_002.pdf (accessed 12 September 2016).

27 Govender \& Hofmeyer (n 26 above).

28 Ramose (n 22 above) 25.

29 As above.

30 Ramose (n 22 above) 26. 
white people retreat into a comfortable position of personal nonculpability. ${ }^{31}$

Secondly, Mbembe maintains that despite white people being born into positions of economic and social advantage, they are reluctant to wash their hands of the privileges they accumulated but instead believe the liberal conservative ideology of the self-reliant and self-made subject and pretend that white racism can no longer be considered the most fundamental cause of black poverty. ${ }^{32}$ Instead white people believe that since blacks now have equality before the law no further action is required and therefore any advocacy for further redress measures or calling for the undoing of a racist legacy all amount to reverse racism. ${ }^{33}$ Such views hinder South Africa's ability to overcome racism because the focus on the part of most white people is on defending their privileged positions in society instead of accepting it as a reality and rather focusing on contributing to finding a solution on how we can improve the disadvantaged position that black people currently occupy in society.

Mbembe finally highlights that white people seem to believe that racial disparities in South Africa are either the result of misguided policies of a corrupt and incompetent black government or the moral failure of blacks who do not work hard enough, do not go to school or are involved in crime and corruption and because of this mentality they are encouraged to absolve themselves from the sins of the past and perceive themselves as the new victims of a corrupt and incompetent black government. ${ }^{34}$ These reactions by white people only serve to perpetuate racism. The TRC aimed to achieve national unity and reconciliation and if achieved I would venture to argue that it should have fostered some willingness on the part of apartheid beneficiaries to change the status quo and improve the quality of life of black people.

\section{A brief analysis of post-apartheid South Africa through Antjie Krog's 'A change of tongue'}

Krog makes a distinction between the terms 'transformation' and 'change'. She believes that transformation and change are two completely different terms. In South Africa there has been change in the sense that the apartheid government with its racist laws have been officially replaced by the ANC and democracy, but despite this

31 A Mbembe 'Apartheid futures and the limits of racial reconciliation' http:// wiser.wits.ac.za/system/files/documents/Mbembe\%20-\%202015\%20-\%20Public\%20 Positions\%20-\%20Apartheid\%20Futures.pdf (accessed 28 April 2016).

32 Mbembe (n 31 above) 6.

33 As above.

34 Mbembe (n 31 above) 10. 
there has been no transformation. ${ }^{35}$ Transformation for Krog is undergoing an internal change which means changing the structures, systems, visions and attitudes that have previously maintained the apartheid system. ${ }^{36}$ If transformation requires an internal change then simply creating legislation to criminalise acts of racism amounts to treating the symptoms and not the disease because the structures, systems, visions and attitudes that inform racism are left unchanged and such an endeavour may prove redundant.

Transformation for Krog is further divided into three phases, namely: the society must be inclusive by providing resources to all those who have been previously excluded, everyone must participate in processes and power structures and there must be consolidation of democracy in all economic, political and social spheres. ${ }^{37}$ If we then apply these standards of transformation to South Africa then it's easy to determine that South Africa has not been transformed, since it has failed to meet each of these phases of transformation. This is clearly depicted in the fact that there is extensive material inequality between blacks and whites, which exists despite formal legal equality being entrenched in South Africa.

Krog in her book discusses the four psychological consequences of racism that can clearly be seen in South Africa today. The first consequence is an intense intra-psychic pain which is caused by internalising the racist messages of the dominant group. This pain leads to the second consequence which is attempting to defend yourself against the racist message. ${ }^{38}$ However since the dominant group is protected by privilege and cannot be attacked, those that are dominated then turn inwards towards themselves and their communities and this results in the abuse of women by men in an attempt to vent their frustration at their circumstances. ${ }^{39}$ It is no coincidence then that in South Africa violence against woman and children is a major problem that continues to plague the country. Violence against women in South Africa has been described as being 'widespread, common and deeply entrenched'. 40

In terms of the effects of racism on white people, Schutte refers to 'the whiteness default', which is created by the deeply held conviction that is entrenched in the white psyche from birth that to be human is to be white. ${ }^{41}$ She acknowledges that the first step for

35 A Krog A change of tongue (2003) 126.

36 As above.

37 Krog (n 35 above) 127.

38 Krog (n 35 above) 150.

39 As above.

$40 \mathrm{G}$ Eagle \& $\mathrm{L}$ Vogelman 'Overcoming endemic violence against women in South Africa’ (1991) 18 Social Justice 209.

41 G Schutte 'The whiteness default: Deconstructing our race indoctrination through a psychoanalytical lens' (2014) 8 PULP Fictions: Race, Ideology and the University 39. 
white people is to admit to their racist indoctrination and unconscious racism and realise that they are part of the global system of dominance which ensures that they are never not benefiting from their whiteness. ${ }^{42}$ Schutte argues that because unconscious racism is still very prevalent it ends up reflecting itself in racial outbursts as seen on social media, therefore it's important to firstly acknowledge its existence and secondly to deconstruct this racism and render it powerless. 43

The third consequence of racism is the psychological double bind which occurs when the dominated group is expected to remain agreeable, pleasant and subservient to the dominant group and if they don't meet these expectations the dominated group is labelled as being problematic and racist. ${ }^{44}$ This psychological double bind then leads to the fourth consequence of racism, which is when the dominated group experiences anger at the psychological double bind that they are in. ${ }^{45}$ Anger is then expressed through violence, addiction and other destructive behaviour. ${ }^{46}$ It is then no surprise that addiction to drugs and alcohol is also a major issue in South Africa as statistics have revealed that roughly one in four adult males and one in ten adult females experience alcohol problems. ${ }^{47}$

An important theme that flows from Krog's book is that of the importance of memory and the importance of not forgetting the past because it is only in remembering and understanding the past that we can understand the present and how to deal with present day issues. ${ }^{48}$ The problem South Africa now faces after apartheid is that the country is in such a rush to build a united rainbow nation that it tends to choose to forget the past and is shocked when remnants of racism emerge. If the country instead of choosing to forget the past focused on moving forward whilst keeping in mind that the events of the past still haunt us in the present, then we would be better equipped to deal with racism. But the question that then arises is if racism remains a valid issue how then do we proceed? I tackle this difficult question next.

\section{$4 \quad$ Utilising Critical Race Theory and African jurisprudence in (post-)apartheid South Africa}

Kok provides that law not only has a limited impact on society, but that it will take time for that impact to be made and the intended

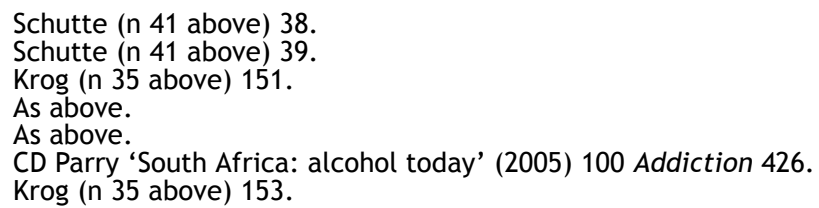


aims may not even be reached. ${ }^{49}$ According to Kok, law plays a very small role in maintaining social order, therefore it has a marginal effect on changing society. ${ }^{50}$ Therefore only using legislation to try and eradicate racism is problematic because legislation may deter the obvious discriminatory acts of individuals, but fails to address racism as a structural power system. If legislation alone is not sufficient then how do we then tackle racism as a structural power system?

\subsection{Critical Race Theory}

An appropriate response to racism as a structural power system would be to utilise CRT, a legal philosophical discipline, which is yet to be formerly adopted in South Africa. ${ }^{51}$ The post-apartheid jurisprudence shows that years of colonialism and apartheid cannot be simply fixed by legislation, but a more radical transformation will be necessary. ${ }^{52}$ CRT is highly useful in the sense that it has aspirations to transform the relationship between race, law and power in order to discontinue the marginalisation of black people. ${ }^{53}$ Critical race perspectives are an important part of any analysis of the South African political, social and legal context because transformation cannot occur without an informed analysis of the current status quo in the country. 54

Critical race theorists follow the approach of 'racial reconstructionism'. This provides that it is still necessary to engage with the concept of race and the implications it has on people and society. ${ }^{55}$ This is especially important, because white people have been taught not to recognise their white privilege and the longer white privilege remains, any effort at equality or transformation will prove unsuccessful. ${ }^{56}$ Therefore CRT rejects the popular colourblindness ideology because despite white people playing a significant part in the construction and replication of racial categories, they now claim to be beyond race and this has the effect of denying black people the right to express their experience of being positioned as black in society. 57

One of the theoretical perspectives of CRT is the critique of liberalism. Liberalism views racism as a rare, irrational and individual problem, while CRT views racism as a systemic and entrenched power

49 A Kok 'Is law able to transform society?' (2010) 1 South African Law Journal 62.

50 Kok (n 49 above) 64.

51 J Modiri 'The Colour of Law, Power and Knowledge' (2012) 28 South African Journal on Human Rights 406.

52 Modiri (n 51 above) 409.

53 Modiri (n 51 above) 414.

$54 \mathrm{~K}$ Van Marle 'Reflections on teaching critical race theory at South African universities/law faculties'(2001) 1 Stellenbosch Law Review 86.

55 Modiri (n 51 above) 412.

56 Modiri (n 5 above) 241.

$57 \mathrm{AE}$ Lewis 'What group? Studying whites and whiteness in the era of colourblindness' (2004) 22 Sociological Theory 624. 
system which discriminates and excludes black people. ${ }^{58}$ As a result of this CRT rejects liberalism's exclusively rights-based approach like anti-discrimination legislation as a way of dealing with racism because such an approach does not address racism as a structural power system. ${ }^{59}$

In South Africa the response to years of discrimination was the Promotion of Equality and Prevention of Unfair Discrimination Act (PEPUDA). PEPUDA was ambitious in its scope as it aimed to criminalise unfair discrimination in all spheres of society and in addition aimed to prevent and prohibit harassment and hate speech. ${ }^{60}$ However, CRT critiques the use of anti-discrimination legislation such as PEPUDA, because while it may address the most blatant forms of racial discrimination, it offers no insight on the structural nature of racism as an ingrained part of society. ${ }^{61}$ PEPUDA came into force in 2003 and the fact that thirteen years later in 2016 the government wants to again enact legislation to criminalise racism as a form of discrimination implies that anti-discrimination on its own is proving ineffective in not only dealing with racism as an ingrained structural power system, but also the blatant discriminatory acts. I do not argue against the creation of legislation criminalising racist acts, but argue against this being the only method of addressing racism because, as stated before, racism is more than discriminatory acts. Therefore some focus should also be directed at racism as a structural power system.

An important element of CRT is intersectionality. CRT understands that people do not only experience racism based on race and, as a result, other factors such as gender and class also play a role in the experience of discrimination and oppression. ${ }^{62}$ In this way different types of discrimination and disadvantage can be identified and appropriate remedies can be applied. ${ }^{63} \mathrm{~A}$ good example of this would be Critical Race Feminism which acknowledges the racial element of gender oppression, which is very relevant in South Africa where black women not only experience oppression for being black, but also for being female; therefore to simply categorise their experience to racism would not be staying true to the actual oppression they experience. ${ }^{64}$ We need to be aware of the different ways in which people experience rights so as to not exclude the experience of others and produce critiques that are not relevant to all

58 Modiri (n 51 above) 415.

59 As above.

60 A Kok 'The Promotion of equality and prevention of unfair discrimination act 4 of 2000: Proposals for legislative reform' (2008) 24 South African Journal on Human Rights 445.

61 Modiri (n 51 above) 416.

62 Modiri (n 51 above) 418.

63 As above.

64 Modiri (n 51 above) 418. 
people. ${ }^{65}$ If South Africa then simply follows the narrow liberal approach of enacting legislation to fight against racism then the element of intersectionality will not be applied and therefore other factors such as gender and class will be ignored despite also playing a role in the oppression people experience.

An important element of CRT is structural determinism, which is concerned with how post-apartheid transformation can take place in a legal culture that maintains the racial status quo. ${ }^{66}$ A conservative legal culture in legal education, adjudication and legal practice hinders justice in the sense that the approach to law tends to be very formalistic and not take into account the different circumstances of people in society. ${ }^{67}$ Justice, in this context, meaning: a racially just society where racial categories will have to be identified so as to ensure that the law is applied in such a manner that substantive equality is applied and the status quo of black people is improved. The problem we face in post-apartheid South Africa is that we are in such a rush to deny that we are still a society that is racist and sexist, that we tend to deny that law and legal institutions are also deeply racist and sexist. ${ }^{68}$

Karl Klare describes the South African legal culture as conservative. ${ }^{69}$ By legal culture he refers to the 'professional sensibilities, habits of mind, and intellectual reflexes' that occur in the legal setting. ${ }^{70}$ This is not necessarily saying that the legal culture is racist, but that it is not open to transforming the status quo of racial inequality. According to Klare, the danger of having a conservative legal culture is that it creates caution which discourages innovative ways of interpretation and application of the constitution. ${ }^{71}$ Klare describes transformative constitutionalism as being a long-term project aimed at transforming 'a country's political and social institutions and power relationships'. ${ }^{72}$ However, transformative constitutionalism becomes a pointless mission if the legal culture in South Africa remains conservative, because a conservative legal culture allows a judge to avoid substantive reasoning and evade a search for justice and presents the law as neutral and objective, when in reality it expresses particular politics and perpetuates the status quo. $^{73}$

65 Van Marle (n 54 above) 87.

66 Modiri (n 51 above) 419.

67 P Langa 'Transformative constitutionalism' (2006) 17 Stellenbosch Law Review 357.

68 Van Marle (n 54 above) 89.

69 K Klare 'Legal culture and transformative constitutionalism' (1998) 14 South African Journal on Human Rights 168.

70 Klare (n 69 above) 166.

71 Klare (n 69 above) 167.

72 Klare (n 69 above) 150.

73 Langa (n 67 above) 357. 
Jurisprudence is described as being the conscience of law and entails exploring law's justice and determining an 'ideal law'. ${ }^{74}$ There are two perspectives upon which the law can be viewed, namely through the lens of restricted jurisprudence or through the lens of general jurisprudence. The current dominant lens through which we currently view the law is through restricted jurisprudence which involves an endless inquisition aimed at determining what the law is and determining its essence. ${ }^{75}$ General jurisprudence on the other hand goes back to classical legal philosophy and encompasses a much wider concept of legality and also scrutinises the legal aspects of social reproduction in and outside of state law. ${ }^{76}$ The question that then arises is through which lens a post-apartheid South Africa should be looked at.

The movement from a general jurisprudence to a restricted jurisprudence has been described as being a story of decline owing to the fact that this movement to restricted jurisprudence has resulted in the moral and cognitive impoverishment of legal theory. ${ }^{77}$ With this in mind it's clear that a return to a general jurisprudence is very necessary because no real transformation will take place in South Africa if legal theory is morally and cognitively impoverished. General jurisprudence includes the political economy of law and the ways in which gender, race or sexuality create forms of identity. ${ }^{78} \mathrm{It}$ is important to rethink the way law is looked at before we even examine how law actually perpetuates forms of oppression on groups of women, black people, homosexuals, etc., because the way in which the problem is approached has an effect on the solution that is chosen. Therefore, a general jurisprudence perspective to the law is essential to attaining real transformation in South Africa.

In order to fully understand how racism has been created and maintained CRT relies on the social science insights, historical analysis and multidisciplinary thinking, in other words general jurisprudence to gain this understanding. ${ }^{79}$ This interdisciplinary approach is applied because racism itself is the result of interdisciplinary effects from different sources and only through this interdisciplinary approach can we fully understand the true extent of racism and ultimately it's the only way to achieve the kind of large scale transformation that is still lacking in post-apartheid South Africa. ${ }^{80}$

C Douzinas \& A Gearey Critical jurisprudence: a textbook (2004) 2. Douzinas \& Gearey (n 74 above) 10. As above.

Douzinas \& Gearey (n 74 above) 4.

Douzinas \& Gearey (n 74 above) 10.

Modiri (n 51 above) 420.

As above. 


\subsection{African Jurisprudence}

One of the shortfalls of the TRC, as discussed above, is the absence of justice which ultimately hinders reconciliation. If we are to one day truly be reconciled, then the detrimental effects of racism need to be confronted, because it is pointless to embark on a mission to eradicate racism without providing a remedy to the wounds it has inflicted. Applying African jurisprudence is the first step. The majority of the South African population is nurtured and educated based on the basic principles of Ubuntu. ${ }^{81}$ Furthermore Ubuntu forms the basis of African Jurisprudence. ${ }^{82}$

The United Nations defined apartheid as a crime against humanity, however in the advent of the constitutional democracy by means of the TRC the crime was not altered, but forgiven. ${ }^{83}$ African jurisprudence firstly requires understanding that racism is an example of the dehumanising effects of colonisation where there was forcible expropriation of land from Africans and, as a result, Africans were forced to enter into the economy and ultimately pushed into a state of poverty. ${ }^{84}$ The constant emergence of racism through mere individual acts of racism to racism as an entrenched power system signifies the fact that we need to remedy the dehumanising effects of colonisation. 85

The main objective of law is to achieve justice and in terms of Ubuntu philosophy justice requires restoring the equilibrium. ${ }^{86}$ Ramose highlights that in terms of Ubuntu philosophy, South Africa should follow a process of decolonisation so as to restore the equilibrium, but it is important to note that decolonisation will entail disregarding the concept of prescription in favour of restoration of title to territory and the reversion of sovereignty over that territory. ${ }^{87}$ Ramose maintains that the processes of democratisation and deracialisation in South Africa have been such a poor success because of the absence of justice through decolonisation. ${ }^{88}$ According to the Ubuntu philosophy, time does not change the truth nor does it correct a wrong, therefore prescription can never justify the forcible

81 MB Ramose 'I conquer, therefore I am the sovereign: Reflections upon sovereignty, constitutionalism, and democracy in Zimbabwe and South Africa' in PH Coetzee \& APJ Roux (eds) The African Philosophy Reader (2003) 487.

82 I Keevy 'Ubuntu versus the core values of the South African Constitution' in S Magadla \& L Praeg (eds) Ubuntu: Curating the archive (2014) 55.

83 MB Ramose 'Historic titles in law' in PH Coetzee \& APJ Roux (eds) The African Philosophy Reader (2003) 462.

84 MB Ramose African philosophy through ubuntu (2005) 6.

85 MB Ramose 'An African perspective on justice and race' (2001) 3 Polylog: Forum for Intercultural Philosophy 12.

86 Ramose (n 85 above) 7.

87 Ramose (n 85 above) 20.

88 Ramose (n 85 above) 22. 
expropriation of land from Africans. ${ }^{89}$ Ramose further argues that prescription is philosophically and materially inconsistent with black peoples' understanding of historical justice. ${ }^{90}$ Prescription is further inconsistent with the legal philosophy of black people as it is deemed to be contrary to natural and fundamental justice. ${ }^{91}$ If the constitution reflects the moral and political convictions of people, then there is no reason as to why Ubuntu should not be the basic philosophy for constitutional democracy in South Africa. ${ }^{92}$ Therefore in order to correct the effects of racism through Ubuntu it will require justice through restoring the equilibrium.

Black consciousness as a form of African philosophy, which was created by Steve Biko, is still very much relevant in post-apartheid South Africa. Biko highlights the fact that the colour issue was originally introduced for economic reasons. ${ }^{93}$ However racism has progressed to become institutionalised and has ultimately become an ordinary part of life with the result that black inferiority is created and is a serious problem. ${ }^{94}$ But any attempts by black people to propose ways of solving the race issue is met with indignation whilst white liberals suggest integration as being the best solution. ${ }^{95}$

Black consciousness suggests that there should be strong solidarity among blacks as the victims of white racism and a realisation that racism is not a mistake but an intentional act. Therefore no amount of moral reprimanding will persuade white people to fix the situation. ${ }^{96}$ According to black consciousness it is important for black people to examine and question old concepts, values and systems and ultimately come up with their own schemes, forms and strategies that will remedy the situation that they are in. ${ }^{97}$ Black consciousness places a duty on black people to come together and fight the position that they have been placed in by racism.

\section{Conclusion}

In this article I critically discussed the law's ability to address racism. In this discussion I established how racism is still an issue despite the efforts of the TRC to achieve reconciliation. The TRC was unsuccessful in achieving reconciliation, firstly, because it did not aim to achieve justice and secondly, total transformation has yet to take place. Only

89 Ramose (n 85 above) 7.

90 Ramose (n 85 above) 20.

91 Ramose (n 81 above) 491.

92 Ramose (n 81 above) 488.

93 S Biko 'Black Consciousness and the quest for a true humanity' in PH Coetzee \& APJ Roux (eds) The African Philosophy Reader (2003) 79.

94 Biko (n 93 above) 79.

95 Biko (n 93 above) 80.

96 As above.

97 Biko (n 93 above) 82. 
once justice and transformation is made a priority can those who have been adversely affected by the structural power system of racism be able to reconcile, but as along as justice remains an issue and transformation is neglected then racism will persist. Krog's 'A Change of Tongue' further highlighted the lack of transformation that has taken place after apartheid and the TRC as well as the effects racism has had on the country.

In order to address the issue of racism as a structural power system that is still in full effect in South Africa I argued that four things need to be taken into account: firstly, we need to formally adopt Critical Race Theory as a legal philosophical discipline so as to understand and be able to correctly deal with how racism still persists despite being morally and legally condemned. Secondly, I argued that the constitution be used to transform society through the transformative constitutionalism project but in order to do this we need to move away from the current conservative legal culture that still applies, because it hinders transformative constitutionalism. Thirdly, I argued that as long as we still look at law through the lens of restricted jurisprudence which gave rise to an impoverished legal theory we cannot achieve transformation, therefore a return to general jurisprudence is necessary. Lastly, we need to invoke African jurisprudence, because in terms of Ubuntu philosophy justice requires restoring the equilibrium and embarking on a process of decolonisation by undoing the dehumanising effects of racism. In addition, the principles of black consciousness should be employed by black people so as to empower black people to remove themselves from the position that they have been placed in through centuries of oppression. Jurisprudence after the TRC should entail giving effect to the demands of justice and transformation as these two things hinder the country from truly being past apartheid as opposed to simply being 'post' apartheid.

Finally, I must agree with the assessment that post-apartheid jurisprudence should include that 'the complexities and tensions of the past, present and future to be heeded and not too easily to be boxed, recorded, methodologised in the guise of practical relevance, 98 because there is no quick, simple and clear cut solution on how to move on from racism as a structural power system that has been entrenched within society through decades of colonialism and apartheid. Whilst legislation criminalising individual acts of racism may be an available solution, it does not mean that other means of addressing racism such as invoking CRT or applying the principles of African jurisprudence should not be investigated and applied. There should be a constant open dialogue on issues of race and how the

$98 \mathrm{~K}$ van Marle 'Jurisprudence, friendship and the university as heterogeneous public space' (2010) 127 South African Law Journal 636. 
embedded structural power system of racism can be deconstructed and ultimately dismantled as current legislation and policies whether it be PEPUDA or affirmative action have proved insufficient in addressing the effects of systemic oppression which include but are not limited to racism and poverty. 